analytical results. Also the experiments were repeated with results entirely in accord with those cited.

We believe the above results strongly indicate that no polyiodide exists to any notable extent in these solutions and that we have here simply a case of "solution in a dissolved solid,"1 a solid which above $82^{\circ}$ has been shown by Abegg and Hamburger ${ }^{2}$ to be itself a remarkable solvent for iodine. We have already pointed out that its behavior in regard to rise in freezing point, decrease in conductivity and distribution phenomena, upon which all claims to complexes in solution are based, have interesting analogies to many ternary mixtures where no such combination would be claimed. The idea of simple solution in a binary solvent has the added advantage that it explains the phenomena of the concentrated solutions equally well with those which are more dilute.

\title{
Summary.
}

No polyiodides of potassium exist as solid phases at $25^{\circ}$.

Potassium iodide and iodine, placed together in aqueous solution, apparently diffuse independently of any chemical combination with each other. Judging from this standpoint alone no polyiodide of potassium is present in solution.

NEW HAMPSHIRE COLLEGE,

DURAAM, N. H.

\section{DIFFUSION PHENOMENA OF THE ALUMS.}

By Charles L. Parsons ann W. W. EvaNs.

Received September 14, igro.

In connection with the diffusion experiments on solutions of iodine in potassium iodide described in the preceding paper and those on known complexes reported in a previous paper by one of us, ${ }^{3}$ it seemed desirable to make preparatory trials on crystal complexes which were known or supposed to exist as a mixture of simpler molecules when dissolved. For this purpose ordinary alum was chosen and the work proved so inter-

1 To explain what is meant by solution in a dissolved solid it may be pointed out that so far as analogy goes the only difference between dissolving potassium iodide in water and water in alcohol is that one is a solid and the other a liquid at the temperature at which most of our ordinary ideas are conceived. Sugar is not soluble in alcohol until water is added, but it is doubtful if any one would claim that the solubility of sugar in aqueous alcohol is due to the formation of sugar hydrates. It is simply because sugat is soluble in water and if one worked at - $I^{\circ}$ it would be a solid we were adding which, after dissolving, in its turn dissolved the sugar. In like manner working at $15^{\circ}$ solid acetic acid dissolving in water acts as a solvent for camphor and the latter gives analogous conditions as to rise in freezing point and decrease in conductivity to those that exist when iodine, itself practically insoluble in water, is brought easily into solution when dissolved potassium iodide is present.

${ }^{2} Z$. anorg. Chem., 50, 403 (Igo6).

* Parsons, J. Physic. Chem., I I, 659 (1907). 
esting that the experiments were extended to other alums and were performed at $0^{\circ}$ and $25^{\circ}$. This paper is written for the purpose of putting these data on record for the different alums studied. Its conclusions are simply confirmatory of previous work.

The alums while crystallizing as complex molecules have long been known to exist as simple sulphates when dissolved. Some early diffusion experiments by Graham ${ }^{1}$ were the first to show that the two sulphates of which ordinary alum is composed can be separated by diffusion. This was later confirmed by Marignac, ${ }^{2}$ who came to the conclusion that double salts like the alums are found only at the moment of crystallization. Later Rudorff, using goldbeater's skin as a separating membrane, ${ }^{3}$ reached much the same conclusion. Gerlach ${ }^{4}$ points out that certain slight volume changes that took place when he mixed solutions of the constituents of the alums indicated the combination of these constituents but his arguments are not convincing when the evidence to the contrary is considered. Besides the above authorities, who argued from a diffusion standpoint, a number of investigations have been undertaken on the cryoscopic and conductivity constants of the alums, of which the research by Jones and Mackay ${ }^{5}$ is perhaps the most complete. They likewise reach the conclusion that the alums exist for the main part only in the solid condition, although they found some evidence that as the solutions grew more concentrated there may have been some association in solution.

In our experiments a known amount of solution was placed either in parchment tubing, which is permeable to the simple constituents of the alums, or in cylinders of agar-agar jelly. These were then placed in beakers containing a measured amount of water and both inner and outer solutions constantly stirred in a thermostat for the periods of time stated below.

The solutions were analyzed by well-known methods and carefully checked. The method used to determine chromium while using wellknown principles we did not find described elsewhere. A measured amount of the chromium solution was diluted to about $\mathrm{x}_{5} \mathrm{O} \mathrm{cc}$. with water, and about I gram sodium peroxide was added, the solution was heated and allowed to boil for about ten minutes, then cooled somewhat and diluted to about $400 \mathrm{cc}$. Then the solution was acidified with $5 \mathrm{cc}$. of sulphuric acid (I: I), 2 grams of potassium iodide were added and the liberated iodine was titrated in the usual manner with a standard solution of sodium thiosulphate. In every case good duplicates could be obtained.

1 Ann. Chem. Pharm., I7, 56 (I851).

Ann. chim. phys. [5], 2, 546 (1874).

s Ber., 2I, 4 (I888).

$1 Z$. anal. Chem., 28, 485 .

- Am. Chem. J., 19, 83 (1897). 


\section{Diffusion of Ammonium Chrome Alum.}

The outside solution in each case was $200 \mathrm{cc}$. water. The experiment was conducted at $25^{\circ}$, each portion being run for three hours. The inside solution contained in $50 \mathrm{cc}$. the alum equivalent to 3.268 grams $\mathrm{Cr}_{2}\left(\mathrm{SO}_{4}\right)_{3}$ and $\mathrm{I} .100$ grams $\left(\mathrm{NH}_{4}\right)_{2} \mathrm{SO}_{4}$, the ratio of mols of each being I: $\mathrm{I}$. Parchment tubing was used.

\begin{tabular}{|c|c|c|c|}
\hline Period. & $\begin{array}{c}\text { COMPOSITION } \\
\left.\mathrm{M}^{\mathrm{Mols}} \mathrm{mols}_{4}\right)_{2} \mathrm{SO}_{4} .\end{array}$ & $\begin{array}{l}\text { DifFusate. } \\
\text { M. mols } \\
\mathrm{Cr}_{2}\left(\mathrm{SO}_{4}\right)_{8} .\end{array}$ & $\frac{\left(\mathrm{NH}_{4}\right)_{2} \mathrm{SO}_{4}}{\mathrm{Cr}_{2}\left(\mathrm{SO}_{4}\right)_{3}}$ \\
\hline I... & $\ldots 5.6$ & I. 228 & $4 \cdot 4^{8}$ \\
\hline $2 \ldots$ & $\ldots \ldots 2.4$ & 1.200 & 2.00 \\
\hline $3 \cdots$ & $\ldots \ldots I .2$ & 0.848 & I. $4 \mathrm{I}$ \\
\hline $4 \cdots$ & $\ldots .0 .36$ & 0.6928 & 0.520 \\
\hline
\end{tabular}

$$
\begin{array}{lll}
0.038 & 0.416 & 0.091
\end{array}
$$

From the above it can be seen that there is an almost complete separation of the constituents of the alum into its components.

\section{Diffusion of Potassium Chrome Alum.}

The inside solution contained in $50 \mathrm{cc}$. the alum equivalent to 1.459 grams potassium sulphate and 3.278 grams chromium sulphate, the molar ratio being $I: I$. The experiment was run as in the previous case, the periods being three hours each and the outside liquid consisting of 200 cc. of water at $25^{\circ}$.

\section{CoMposition OF DTFFUSATE.}

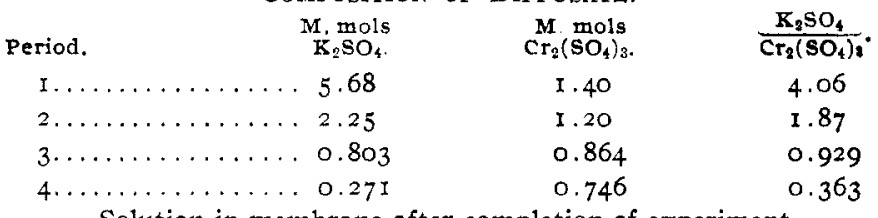

Solution in membrane after completion of experiment.
0.0688
I.OI2
0.068

It can be seen that the same separation takes place as in the previous case.

\section{Diffusion of Potassium Aluminium Alum.}

Inside solution contained in $50 \mathrm{cc}$. alum equivalent to 1.455 grams potassium sulphate and 2.856 grams aluminium sulphate, molar ratio

\begin{tabular}{|c|c|c|c|}
\hline Period. & $\begin{array}{c}\mathrm{M} . \text { mols } \\
\mathrm{K}_{2} \mathrm{SO}_{4} .\end{array}$ & $\begin{array}{c}\mathrm{M} . \\
\mathrm{Al}_{2}\left(\mathrm{SO}_{4}\right)_{8}\end{array}$ & $\frac{\mathrm{K}_{2} \mathrm{SO}_{4}}{\mathrm{Al}_{2}\left(\mathrm{SO}_{4}\right)_{3}}$ \\
\hline I... & $5.7 \mathrm{I}$ & I. 28 & $4 \cdot 46$ \\
\hline $2 \ldots$ & . 2.05 & 0.958 & 2.14 \\
\hline $3 \ldots$ & 0.775 & 0.855 & 0.906 \\
\hline $4 \cdots$ & 0.247 & 0.606 & 0.408 \\
\hline
\end{tabular}
I: I. Details the same as in previous cases.

Composition of Diffusate.

Solution in membrane after completion of experiment.

$$
\begin{array}{lll}
0.1049 & 0.1145 & 0.916
\end{array}
$$




\section{Diffusion of Ammonium Aluminium Alum.}

Inside solution contained in $50 \mathrm{cc}$. the alum equivalent to. I.IOI4 grams ammonium sulphate and 2.852 grams aluminium sulphate, molar ratio I: I. Details same as in previous cases.

\section{Composition of Diffusate.}

\begin{tabular}{|c|c|c|c|}
\hline Period. & $\begin{array}{c}\mathrm{M} \cdot \mathrm{mols} \\
\left(\mathrm{NH}_{4}\right)_{2} \mathrm{SO}_{6}\end{array}$ & $\begin{array}{c}\mathrm{M} \cdot \mathrm{mols}_{2}\left(\mathrm{SO}_{4}\right)_{3} \\
\mathrm{As}^{2}\end{array}$ & $\frac{\left(\mathrm{NH}_{4}\right)_{2} \mathrm{SO}_{4}}{\mathrm{Al}_{2}\left(\mathrm{SO}_{4}\right)_{3}}$ \\
\hline I & 5.6 & $3 \cdot 5^{2}$ & I. 59 \\
\hline $2 \ldots$ & $\ldots \quad$ I. 85 & 0.696 & 2.80 \\
\hline $3 \ldots$ & $\ldots 0.70$ & 0.571 & I. 22 \\
\hline $4 \ldots$ & $\ldots 0.50$ & 0.875 & 0.58 \\
\hline
\end{tabular}

Solution in membrane after completion of experiment.
0.35
0.355
0.98

There was probably some error which entered in the first period, as can be seen from the ratio.

\section{Diffusion of Ferric Ammonium Alum.}

The inside solution was made up so that $50 \mathrm{cc}$. contained the alum equivalent to I.IO3 grams ammonium sulphate and 3.334 grams ferric sulphate, molar ratio being $I: I$. Details same as in previous cases.

Composition of Diffusate.

\begin{tabular}{|c|c|c|c|}
\hline Period. & $\underset{\left(\mathrm{NH}_{4}\right)_{2} \mathrm{SO}_{4}}{\mathrm{mols}}$ & $\underset{\mathrm{Fe}_{2}\left(\mathrm{SO}_{4}\right)_{3}}{\mathrm{M} . \operatorname{mols}^{2}}$ & $\frac{\left(\mathrm{NH}_{4}\right)_{2} \mathrm{SO}_{4}}{\mathrm{Fe}_{2}\left(\mathrm{SO}_{4}\right)_{8}}$ \\
\hline I. . & . 5.12 & 2.93 & I. 74 \\
\hline $2 \ldots$ & $\cdots 3.24$ & 2.54 & 1.27 \\
\hline 3. & $\ldots 0.560$ & I. 78 & 0.315 \\
\hline $4 \ldots$ & . o.160 & 0.622 & 0.257 \\
\hline
\end{tabular}

Solution in membrane after conclusion of experiment.
0.160
0.570
0.287

It was found that in this case there was a tendency on the part of the iron toward hydrolysis, heightened by the removal of the ammonium sulphate. This interfered with the diffusion through the membrane and therefore this separation is not so perfect as in the case of the other alums. However, as can be seen from the above, there is no doubt that separation takes place.

\section{Diffusion at Low Temperature.}

Experiments were also conducted in a mixture of snow and water, the temperature being close to $0^{\circ}$, to see what effect a decrease in temperature would have upon the results. In other respects the work was carried on as before.

\section{Diffusion of Ammonium Chrome Alum.}

Inside solution same as before, $50 \mathrm{cc}$. containing the alum equivalent to 1.100 grams ammonium sulphate and 3.268 grams chromium sulphate, molar ratio $I: I$. The temperature was kept constant by the use of 
a snow water mixture. Time of each period three hours. Parchment tubing used.

\begin{tabular}{|c|c|c|c|}
\hline Periogi. & $\underset{\left(\mathrm{NH}_{4}\right)_{2} \mathrm{SO}_{1}}{\mathrm{M} \cdot \mathrm{mols}}$ & $\begin{array}{l}\text { II. mols } \\
\mathrm{Cr}_{2}\left(\mathrm{SO}_{4}\right)_{3} .\end{array}$ & $\frac{\left(\mathrm{NH}_{4}\right)_{2} \mathrm{SO}_{4}}{\mathrm{Cr}\left(\mathrm{SO}_{4}\right)_{3}}$ \\
\hline I... & $\cdots 3.60$ & 0.552 & 6.52 \\
\hline $2, \ldots$ & $\ldots 2.20$ & 0.520 & $4 \cdot 44$ \\
\hline $3 \ldots$ & $\ldots \dot{I} .24$ & 0.453 & 2.74 \\
\hline $4 \ldots$ & $\ldots \quad 0.88$ & 0.426 & 2.06 \\
\hline
\end{tabular}

Solution left in membrane after close of experiment.
0.187
1.83
0.0122

\section{Diffusion of Potassium Chrome Alum.}

Inside solution as before, $50 \mathrm{cc}$. containing an amount of the alum equivalent to 1.459 grams potassium sulphate and 3.278 grams chromium sulphate, molar ratio I: I. Details as above.

\begin{tabular}{|c|c|c|c|}
\hline \multicolumn{4}{|c|}{ COMPOSITION OF DIFFLSATE. } \\
\hline Periud. & $\underset{\mathrm{K}_{2} \mathrm{SO}_{4}}{\mathrm{M} \text { mols }}$ & 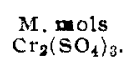 & $\frac{\mathrm{K}_{2} \mathrm{SO}_{4}}{\mathrm{Cr}_{2}\left(\mathrm{SO}_{4}\right)_{3}}$ \\
\hline I. & 3.80 & 0.880 & $4 \cdot 32$ \\
\hline $2 \ldots$ & 2.50 & 0.506 & 4.94 \\
\hline 3. & 0.736 & 0.466 & I. 59 \\
\hline $4, \ldots$ & 0.665 & 0.440 & I. 50 \\
\hline
\end{tabular}

Solution in membrane after conclusion of experiment.
0.0143
2.075
0.007

From the above work it can be seen that there is a separation at $0^{\circ}$ as well as at $25^{\circ}$. The molecules at this temperature move more slowly as one would expect; consequently the separation of the two is not so rapid as at higher temperatures, but it is more complete.

\section{Diffusion through Agar Jelly.}

Graham has shown ${ }^{1}$ in working with agar-agar jelly that mixtures of salts diffuse readily from aqueous solutions and that the diffusion constants do not change with rise of temperature but the amount of diffused salt regularly increases. He found that the rate of diffusion is practically the same for different concentrations of the jelly.

For our experiments a cylinder of the jelly closed at one end was made from a 3 per cent. solution, having walls about I I mm. thick. The alum solution was placed inside and allowed to diffuse out into $150 \mathrm{cc}$. of water. The temperature was kept at $25^{\circ}$ throughout the experiments. Each portion was run for a period of 24 hours and the portions analyzed.

\section{Diffusion of Ammonium Chrome Alum.}

The solutions used were the same as in the previous work. Periods 24 hours each.

'J. Chem. Soc., 56, 816. 
Composition of Diffusate.

\begin{tabular}{|c|c|c|c|}
\hline Period. & $\underset{\left(\mathrm{NH}_{4}\right)_{2} \mathrm{SO}_{4} .}{.}$ & $\underset{\mathrm{Cr}_{2}\left(\mathrm{SO}_{4}\right)_{3}}{\mathrm{mols}}$ & $\frac{\left(\mathrm{NH}_{4}\right)_{2} \mathrm{SO}_{4}}{\mathrm{Cr}_{2}\left(\mathrm{SO}_{4}\right)_{8}}$ \\
\hline I. & . 2.28 & 0.426 & $5 \cdot 35$ \\
\hline $2 \ldots$ & I. 26 & 0.810 & I. 55 \\
\hline $3 \ldots$ & .0 .90 & 0.720 & 1.25 \\
\hline
\end{tabular}
0.05
0.13
0.039

Diffusion of Ammonium Aluminium Alum.

Solutions same as previously used. Periods 24 hours each.

Composition of Diffusate.

\begin{tabular}{|c|c|c|c|}
\hline Period. & $\underset{\left(\mathrm{NH}_{4}\right)_{2} \mathrm{SO}_{4} .}{\text { mols }}$ & $\begin{array}{l}\text { A. mols } \\
\mathrm{Al}_{2}\left(\mathrm{SO}_{4}\right)_{3} .\end{array}$ & $\frac{\left(\mathrm{NH}_{4}\right)_{2} \mathrm{SO}_{4}}{\mathrm{Al}_{2}\left(\mathrm{SO}_{4}\right)_{3}}$ \\
\hline I.... & . . I. 62 & 0.585 & 2.77 \\
\hline $2 \ldots \therefore$ & I. 26 & 0.792 & 1.28 \\
\hline \multicolumn{4}{|c|}{ Solution in cell after conclusion of experiment. } \\
\hline & 0.70 & 0.138 & 0.507 \\
\hline
\end{tabular}

The results of these experiments with agar-agar show in the same way as with parchment that the constituents of the alums diffuse independently.

\section{Conclusions.}

When alums are dissolved in water they are decomposed into the simple sulphates, which can be separated from each other by diffusion. The chrome alums separate more readily than the aluminium alums. This is in entire accord with previous researches.

\section{THE SOLUBILITY OF BARIUM NITRATE AND BARIUM HYDROX- IDE IN THE PRESENCE OF EACH OTHER.}

BY C. L. PARsons AND H. P. CORSON.

Received September I4, IgIO.

The work of Cameron and Robinson upon the system lime, nitric acid and water ${ }^{1}$ proves the existence of a basic nitrate of calcium having a composition represented by $2 \mathrm{CaO} \cdot \mathrm{N}_{2} \mathrm{O}_{5} \cdot 3 \frac{1}{2} \mathrm{H}_{2} \mathrm{O}$. Their work suggested the possibility of the existence of similar compounds of barium, but in a careful search of the literature we were unable to find any record of such work upon barium. Hence the present investigation was undertaken.

A specially prepared barium nitrate obtained for this research was carefully tested for impurities. The salt was found to be very pure, no foreign substance being detected except a small amount of carbonate. A saturated solution of the nitrate was prepared and made slightly, yet distinctly, acid with nitric acid and boiled to remove carbon dioxide.

The barium hydroxide obtained for the work was found to be quite

'J. Physic. Chem., 2, 273 (I907). 